\title{
My Cry Gets Up to My Throat \\ Dysplacement, Indigenous Storywork, and Visual \\ Sovereignty in the Mandan Hidatsa Arikara Nation
}

Jennifer Shannon

\begin{abstract}
The repatriation of sacred objects from the University of Colorado Museum of Natural History to the Mandan Hidatsa Arikara Nation in North Dakota established the foundation for a long-term research partnership that resulted in an oral history project and documentary about the life and times of a missionary to the reservation in the past, and it provided a means for elders to historicize the present and communicate to the next generation their concerns about contemporary times. Through a collaborative filmmaking process that highlighted visual sovereignty and engaged in Indigenous storywork, the resulting video represented the past in the community members' own terms, sparked dialogue in community vetting sessions about the oil boom, and became a teaching resource for the tribal college.
\end{abstract}

In a US Army Corps of Engineers promotional reel, a man's booming voice assertively announces:

When the dam was dedicated in 1946, General Pick said, this is a new beginning of a new era for the people of the Missouri River basin. Through the engineering knowledge acquired by mankind another destructive natural force will be harnessed to serve man usefully. Federal agencies participating in this program are all represented in the inter-agency committee. These representatives along with 5 governors selected from the 10 interested states are the controlling body in matters concerning development of the Missouri river basin. ${ }^{1}$

Sixty-six years later Tillie Walker speaks back-directly to the camera, to her community and to the world: 
We were against a big, big operation. They decided that they were go-

ing to build the dam and drown us out. That was their pattern. No

matter what we did, I don't think it would have helped. . . . It was an 3 awful time because we had lived along the Missouri River, that was 4 our homeland since the beginning, and it was as though it meant absolutely nothing to the people who made those plans. And they saw us as easy to move and get out of their way so they could build the dam.

The vehicle for Ms. Walker's counter-narrative is the documentary $M y$ Cry Gets Up to My Throat: Reflections on Rev. Case, the Garrison Dam, and the Oil Boom in North Dakota (Shannon 2014a). Ms. Walker and her family, along with 90 percent of the families on the Fort Berthold Reservation in North Dakota, were forced to relocate in 1952 as a result of the Garrison Dam (Berman 1988). Today, as you drive through Fort Berthold, you see a large lake with a bridge at its north end connecting the northwest and northeast segments of the reservation. It seems like a peaceful, beautiful body of water, but beneath it are Elbowoods and other reservation towns, homes, and buried ancestors, and it represents pain and loss to those who were forced to leave their homelands, the bottomlands of the Missouri River.

The title of the video comes from a reminiscence from elder Edwin Benson:

I guess all the people that missed that river bottom, well I for one, I still miss that. When I go home, north here, look down over them hills, it's still home to me. The old hills where I used to ride horseback and go around, some of them are still there. Then when I see them, I feel bad, and my cry gets up to my throat here. And I swallow it, and come home. But it will always be that way as long as I live. I have to go to church with my maker, one day, with that feeling, hanging on yet. And all them that passed on must have went with the same feeling.

Elder Ed Hall echoed Mr. Benson's sentiment, pointing to the lake while

he told me he was "born and raised under the water" at a town called Elbowoods (Shannon 2018).

My Cry Gets Up to My Throat is the result of a digital heritage project that illustrates how doing museum anthropology led to a collaborative video making project-its role in strengthening relations between museum and originating community and in transmitting knowledge from 
one generation to the next. The video was based on a story, and consultation, related to a museum collection. Beyond a new, born-digital item for the museum collection, the video produced through collaboration with Mandan Hidatsa Arikara Nation members living at Fort Berthold and the collection donor's family has shown how museum collections, conceived of here as tangible/material culture and intangible/oral history video, can become an impetus and resource for community members to reflect on and tell their own history.

My Cry Gets Up to My Throat was produced at the request of cultural specialists and elders in the Mandan Hidatsa Arikara (MHA) Nation after a repatriation consultation at the University of Colorado Museum of Natural History. These things are related. To many Native community members, museums represent a legacy of taking from them-disinterring and taking their ancestors to be treated as specimens for science, taking sacred and ceremonial objects in times of duress. This is seen as part of a larger colonizing process that included the taking of children from their homes, and the taking of lands and languages from their peoples. But these efforts were not wholly successful, and today Native communities communicate their agency and resilience in the face of this history in many ways to educate and inspire their next generations. In the context of historical trauma, collaborative museum anthropology and visual sovereignty have roles to play in supporting Native community members to understand and recount the past on their own terms, act in the present, and prepare for the future. Through acts of repatriation, more culturally appropriate representation in museums, and facilitating visual sovereignty as a form of "Indigenous storywork" (Archibald 2008), these efforts are part of a larger commitment to restorative justice (Colwell 2019; Simpson 2009).

\section{Visual Sovereignty and Indigenous Storywork}

In museum anthropology, where collaboration with Indigenous peoples is now expected (Thomas 2010), video can be an important tool in the collaborative process as well as a desired outcome of it. I have argued elsewhere that contemporary museum anthropology is collaborative anthropology (Shannon 2015); it is also increasingly a visually oriented anthropology, entailing collaborative video production. I do not mean this simply in the way that audiovisual materials are so prev- 
alent in museum exhibitions and in the interpretation of material culture (cf. Herle 1990) - although that has become a prominent strategy for the exhibition of Native American collections to indicate, through video interviews for example, that Native peoples are still here and interpreting their own history, life experiences, and cultural materials (cf. Fienup-Riordan 1999, 343-44). I am specifically referring to the increasing use of video as born-digital collections that document the process of working with Indigenous peoples, and their increasing demands that we share our research in more accessible formats (see for example Butler et al. 2011; Glass 2004; Hennessy et al. 2013; Olin 1983).

When MHA Nation community members invited me to create an oral history documentary with them, they were in part seeking to establish visual sovereignty over the narrative of their past, and the perspective it privileges, as well as over how that narrative will inform and guide understanding about their future. Raheja $(2007,1161)$ explains that "visual sovereignty" is a strategy that:

offers up not only the possibility of engaging and deconstructing white-generated representations of indigenous people, but more broadly and importantly how it intervenes in larger discussions of Native American sovereignty by locating and advocating for indigenous cultural and political power both within and outside of Western legal jurisprudence.

Raheja sees video in particular as an "exciting site for exploring how sovereignty is a creative act of self-representation that has the potential to both undermine stereotypes of indigenous peoples and to strengthen what Robert Warrior has called the 'intellectual health' of communities in the wake of genocide and colonialism" (Raheja 2007, 1161). My Cry, in 28 its intent and its content, in its delivery and its distribution, was clearly an act of visual sovereignty.

Santa Clara Pueblo filmmaker and scholar Beverly Singer describes 31 Native filmmaking as part of a movement for "cultural sovereignty" 32 (Singer 2001, 2). She explains that filmmaking is a novel medium to continue the tradition of Native storytelling that has endured through generations, and that understanding oral tradition is "fundamental to understanding Native film and video and how we experience truth, impart knowledge, share information and laugh ... one of the reasons for making films is to heal the ruptures of the past, recognizing that such healing is 
up to the viewer" (Singer 2001, 2-3) -and that these are "ruptures of our history related to colonialism, disease, and cultural loss" (Singer 2001, 9). An example of a collaborative filmmaking project that demonstrates this is Gathering Strength (2014) by Gitxaała scholar and filmmaker Charles Menzies. The film follows a canoe journey that "itself is an explicit act of cultural discovery and an assertion of cultural continuity" (Menzies 2015, 107). Through documenting this journey, community members highlighted to the young people in their lives an acknowledgment of their struggle and the "potential for personal growth and well-being through a grounding in one's own culture" (Menzies 2015, 107).

I would argue that MHA community members engaged in visual and cultural sovereignty, and efforts to heal these ruptures and increase wellbeing, through the method of what scholar Jo-ann Archibald from Stó:lō Nation (2008) calls "Indigenous storywork." Although I did not recognize it as such or call it that at the time, community members were bringing me into this process of "using First Nation stories and storytelling for education," where stories can be traditional stories or personal life experiences (Archibald 2008, ix). Archibald uses the term storywork to insist that Indigenous stories and storytelling "be taken seriously," and she highlights their application in education. At the heart of Indigenous storywork are the "cultural values of respect, responsibility, reciprocity, and reverence" (Archibald 2008, 85). When non-Native researchers or educators engage in oral history or recount Indigenous stories, it can lead to appropriation or inappropriate use of them; learning cultural protocols, following elders' guidance, and utilizing a storywork framework can help mitigate these potential harmful outcomes (Archibald 2008, 150). To conduct the interviews and take direction from elders required being "culturally 'worthy' or 'ready"' (Archibald 2008, 108). I believe my readiness was determined in part as a result of the relationships established through my work with community members on the repatriation of sacred objects from our museum and my commitment to collaborative museum anthropology.

Collaborative museum anthropology engages in the movement to "decolonize museums," a practice that acknowledges the troubled history and power imbalance between museums and Indigenous peoples. ${ }^{2}$ It involves working with originating communities to access and appropriately care for, interpret, and display the items in museum collections that come from their communities. ${ }^{3}$ Efforts to decolonize the museum and partner- 
ing with Native communities have most often been focused on how we make exhibitions or conduct collections research-collaboratively, with co-directed goals (Shannon 2014c). But as Amy Lonetree (2012) argues, it must also be focused on what the exhibitions are about: telling the "hard truths of colonialism." There are thoughtful critiques about the impetus by dominant cultures to include and collaborate with indigenous peoples (Jones and Jenkins 2008; Mithlo 2004). These kinds of concerns about whom the collaboration benefits, and why, informed our emphasis on co-direction of the project and its outputs, but the concerns these authors raise cannot be entirely resolved. Based on the notion of decolonizing the museum, and keeping in mind Boast's (2011) cautions against neocolonial collaboration that serves only the museum institution and not the community, the oral history project discussed here was based on the following principles: develop research practices and goals together; practice a collaborative ethic and shared authority; provide greater access to collections; facilitate self-representation; acknowledge histories of oppression; inform and expand public perceptions about Indigenous peoples; use advanced technology and multimedia to engage underserved communities; and build lasting relationships.

\section{Repatriation as a Foundation for Research}

The University of Colorado Museum of Natural History (UCMNH)

From when tribal representatives signed the Fort Laramie Treaty in 
to this reduction in lands was the Garrison Dam, completed in 1953 by the US Army Corps of Engineers-another large-scale event that community members identify, like smallpox in the nineteenth century, as contributing to historical trauma. The dam created a reservoir covering 155,000 acres that were home to the most precious lands and settlements on the reservation. The flood devastated the MHA community, inundating homes and relocating 90 percent of tribal members to other parts of the reservation (Berman 1988; Lawson 2009). Tribal members moved from the fertile Missouri River bottomlands to the harsher bluffs above, scattered into six different segments separated by the newly created lake. MHA community members were relocated not only to other areas of the reservation in the early 1950 os but also to cities like Chicago, Los Angeles, and Denver as part of a broader US policy later formalized in the Indian Relocation Act of 1956. This act aimed to move Native Americans away from reservations, provide them with employment assistance, and in so doing support the government's policy of termination, which focused at the time on dismantling reservations and terminating the government's trust responsibility to tribes (Fixico 2000, 10).

Reverend Harold Case was a missionary who lived at Fort Berthold during these times; he arrived at the reservation in 1922 and continued to work there for over forty years (Maxfield 1986). It was an especially traumatic time for the community in the 1940s and 1950s when the US government planned and constructed the Garrison Dam project. As historian Marilyn Hudson notes, "in the end the people, seeing that it was inevitable, agreed to the Garrison Dam" by voting for the project. They hoped in doing so that they would get better value for their confiscated lands. ${ }^{5}$

A consultation under the Native American Graves Protection and Repatriation Act (NAGPRA) with the MHA Nation regarding sacred objects in the collection donated by the Case family laid the foundation for the oral history video project. NAGPRA liaisons Calvin Grinnell, MHA tribal historian and president of the State Historical Society of North Dakota at the time, and Elgin Crows Breast, MHA tribal historic preservation officer at the time, had visited the museum in 2007 for a consultation on Native ancestors or human remains. During that visit they had expressed interest in some ethnographic items in our collection that might also fall under the law. ${ }^{6}$ After I was hired in 2009, I invited them to participate in a NAGPRA consultation and documentation grant to 


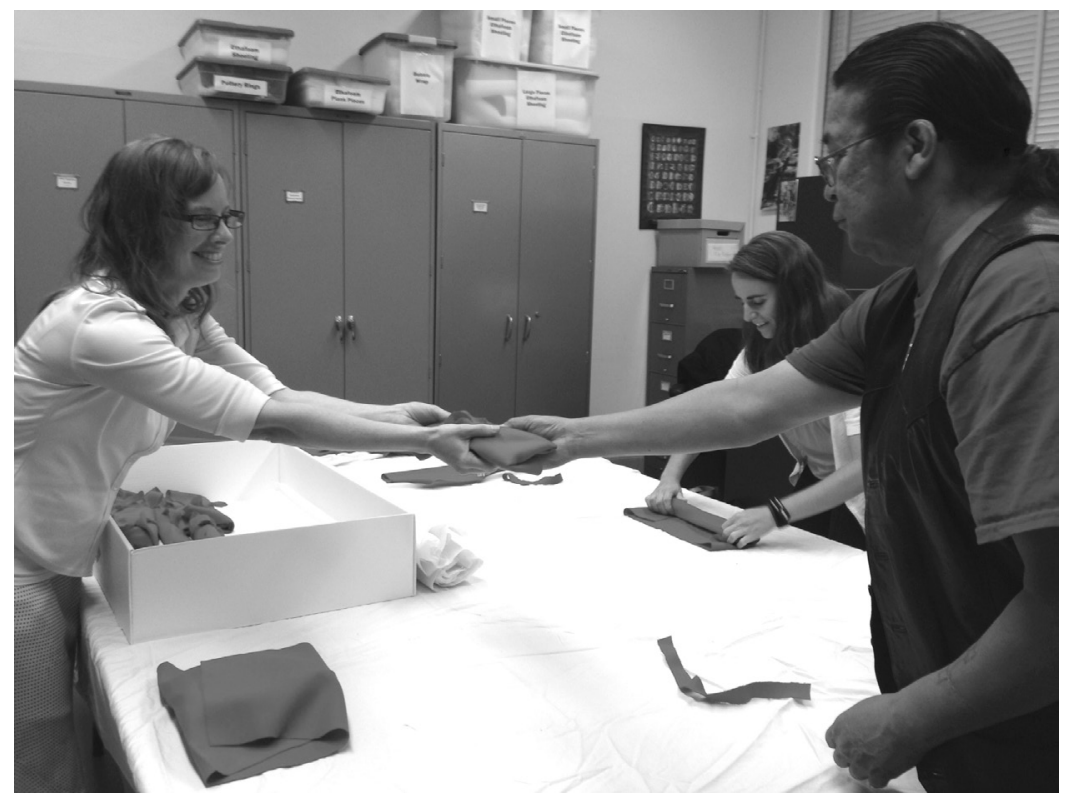

Fig. 1. UCMNH Collections Manager Christina Cain, author, and Elgin Crows

Breast preparing items to return to the MHA Nation. Photo by Jan Bernstein.

Shared with permission from NAGPRA liaisons.

inventory and consult on the cultural items in our collection to deter-

mine if they are sacred items or items of cultural patrimony and thus

eligible under the law to be requested for return to the tribe. In 2011 we

were awarded the grant and began the consultation process, which led to

the repatriation of sacred objects in 2014 (figure 1). From our meetings

together, we began a working relationship that developed into a research 28 partnership.

When I asked Mr. Grinnell and Mr. Crows Breast whether they want30 ed us to do any further research about the MHA collections in the mu31 seum, they invited me to meet with them and a group of elders at Fort 32 Berthold Reservation in 2011 to discuss possibilities. The elders said they 33 wanted us to investigate a particular subject that was a surprise to me: 34 the "life and times of Reverend Case," who had amassed the collection of 35 MHA items and whose family had donated it to the museum. ${ }^{7}$ They told 36 us they wanted to better understand the life and times of this missionary who, as Mr. Crows Breast put it, "eased their pain" during this "difficult 
transition." Or, as Ed Hall asked us to investigate, why would Rev. Case come so far from the comfort of his home on the East Coast and stay a lifetime? In addition, as community members explained, the research we began in 2011 was timely given the subject matter and the age of those who personally knew Rev. Case: "Reverend Case's memory lives on in the hearts and minds of many of our tribal members today, although most of them are over 55 years old today. That is why it is extremely timely that a project of this scope be initiated as soon as possible. Many of our people have health issues which has shortened our lifespan considerably, no doubt as a direct result of this massive relocation of our communities to the bench lands surround[ing] the Garrison Reservoir now called Lake Sakakawea."

This advisory group not only explained what they wanted us to research, but also how: they wanted us to conduct oral history video interviews. And they insisted that an edited documentary would be an important outcome of our work together. ${ }^{9}$ When we posed this to Rev. Case's grandchildren, they wholeheartedly agreed to this focus and offered to share their private photo collection digitally in service of the partnership as well. ${ }^{10}$ Together with the MHA advisory group and the Case family, we determined the outputs of our work together to include: the return of sacred objects through NAGPRA; an oral history video archive about the life and times of Rev. Case to be housed at the UCMNH and the Three Tribes Museum; and an edited documentary. In addition, in preparation for the repatriation consultation we created a password protected website with images of all the MHA items in our museum collection for review by the NAGPRA liaisons. This site was later made available to the Case family and MHA community members and includes not only the museum collection images but also the documentary, images from a new photographic archive created from digitized private Case family photos, and over two thousand scanned archival photos from the Rev. Case archives at the State Historical Society of North Dakota. ${ }^{11}$

Through our collaboration and in the resulting documentary, MHA community and Case family members reflect on Rev. Case, his role in the community, his assistance during a difficult time of transition for the MHA Nation, his efforts to stop the removal of the MHA Nation from their homelands, and how the times in which he lived influence how people think about what is happening in the community today. During the making of the video, the reservation was at the center of an oil boom 
facilitated through the hydraulic fracturing process, or fracking, which enabled access the Bakken Shale. In connecting the Garrison Dam project to fracking and the oil boom, oral history shows how our experiences of the past shape how we understand the present and prepare for the future. As one community member stated, "The Oil Boom is the Garrison Dam of my generation." ${ }^{12}$

\section{Collaborative Process}

Being open to unpredictable outcomes and taking time to build relationships and trust are key features of a museum anthropology that embraces slow museology (Silverman 2014), as the outcomes are collaboratively directed and often unanticipated, like this video project. We achieved this in part because we relied on several small grants over the years, rather than an artificial and compressed timeline determined by, say, a large grant (see Shannon 2014c). In addition, our community partners understood that we were not professional filmmakers, and did not expect a polished film. With a Sony HD Camcorder, a tripod, wireless mics, and some portable lights-along with university student assistants-we were able to accomplish a video documentary that was approved and appreciated by the people with whom we worked.

We ended up working in a comparable way to Sarah Elder's "community directed filmmaking," which she had done in the Arctic in the 1970s, later altering the name to "community collaborative filmmaking" in the 1980s (Elder 1995, 98). We experienced similar guidance from community members, which led to a comparable process of shared authorship, and we held similar concerns about representation and sensitivities to consent. However, due to prohibitive costs associated with travel to the Arctic, Elder was unable to show the community with whom she worked the final cut of the film. Because the MHA community was only an eleven-hour drive away, we were able to visit multiple times at different stages in the development of the documentary. And showing the final cut of the video initiated important group discussions that led to an interest in our pursuing a second documentary project, which began in August 2015 (and ended up in a very different place from where we started!-see Shannon 2017).

Whenever talking about collaboration, it is important to be precise about the roles of the participants. Our primary research partners were 
Elgin Crows Breast, Calvin Grinnell, and Marilyn Hudson, tribal historian and administrator of the Three Tribes Museum. ${ }^{13} \mathrm{Mr}$. Crows Breast was mainly responsible for bringing the advisory group together during our first visit to MHA Nation, and he introduced us to most of the people interviewed on video, sometimes bringing them to the Three Tribes Museum where we had our video equipment set up. Mr. Grinnell and Ms. Hudson also introduced us to interviewees and provided regular feedback on our progress, including helping to identify appropriate themes, editing the narrative script, and suggesting which video clips to include or exclude (and providing feedback on this article). My own role for the video project was interviewer, camera person, director, and producer. I worked with a variety of students in these various capacities, most notably Lex Mobley, an undergraduate Film Studies major who co-wrote the script with me based on transcripts of the interviews; she edited the video. MHA community members were very gracious in accepting their powerful stories wrapped in a more amateur package than what a professional documentary team might produce.

While we had worked with our small advisory group to develop appropriate questions for our oral history interviews about Rev. Case, it was community members' responses to my final interview question that started to shape the narrative into a cohesive and timely story. With the simple question, "Is there anything else you'd like to add?", almost every person discussed the oil boom. As James Bear put it, "The oil boom is another story that needs to be told." At the final film screening in November 2015, community members discussed this and the idea was born for a second documentary, focusing on contemporary life.

The timeline and iterative process to create My Cry Gets Up to My Throat stretched over four years (figure 2). After our initial interviews, Lex and I selected clips based on common themes and showed them in community meetings in 2013. We developed a first draft narrative from feedback on these themes, and then developed a draft video without " $b$ roll," or video clips that are secondary footage used to provide context or visual examples of what is being talked about in the story, and showed that the following year. It was important to convey to the various groups on the reservation to whom we screened this draft that it was incomplete and awaiting their input. So the title at the start of the video was "What do you think the title should be?" to encourage feedback and the sense that this was unfinished work. We received substantive feedback, such as 

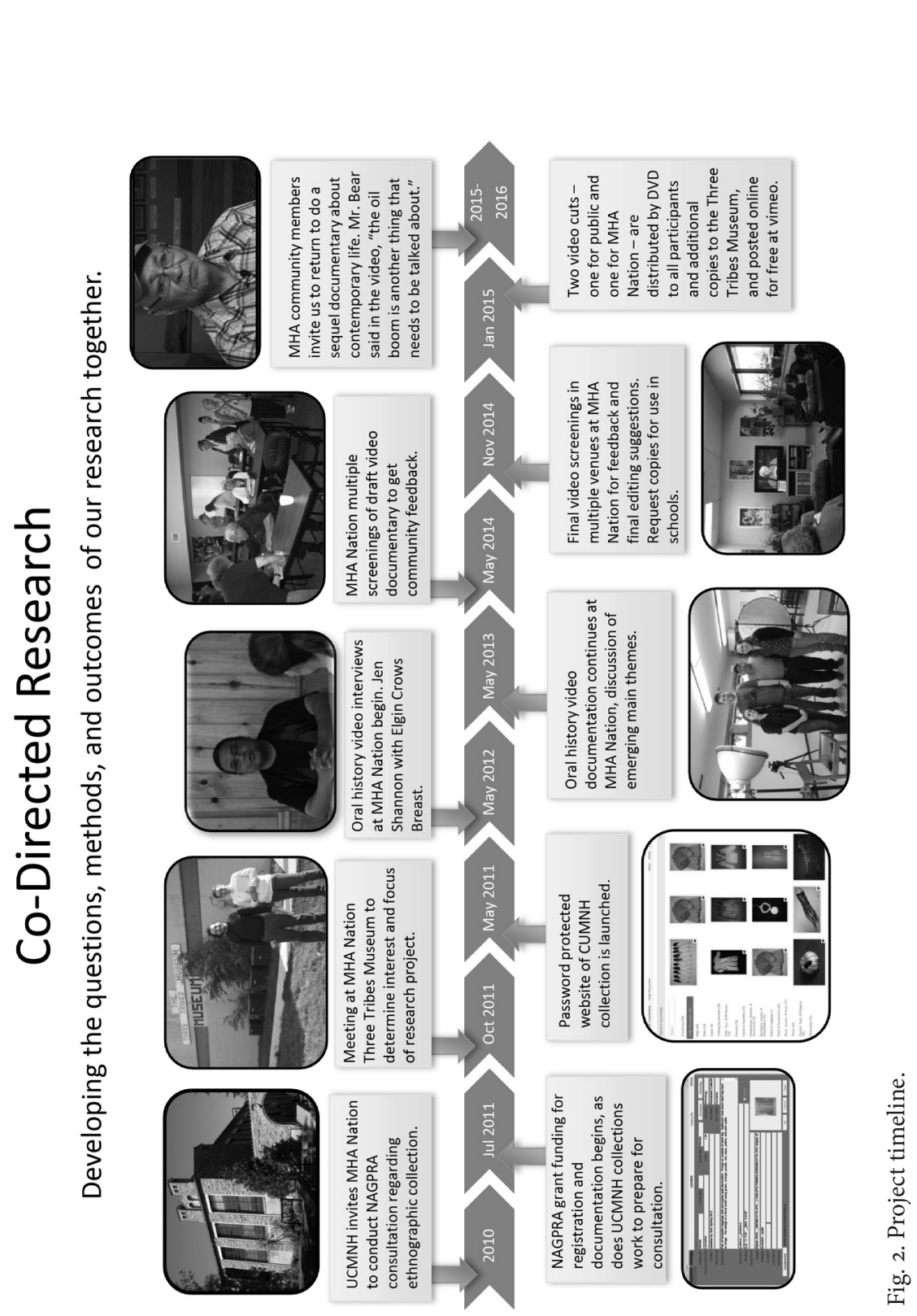
removing one clip, and what kinds of "b roll" we might add to the stories being told. We also conducted additional interviews at this time, as word about the project was spreading.

In November 2014 we showed the final cut at various locations on the reservation. We then produced two versions of the documentary: an MHA Cut that is one hour long with lengthier interviews and additional information about the museum, the NAGPRA consultation, and the MHA collection; and, the Public Cut, which is 47 minutes long and edited for the general public, who may not have as much background knowledge of the MHA Nation. All interviewees received copies of their raw uncut interviews and the MHA Cut. The Three Tribes Museum received twenty-five copies on DVD for free distribution, and we responded to requests for additional copies of both versions from MHA community and Case family members. The two versions of My Cry Gets Up to My Throat were also posted for free online access at Vimeo and the interactive community website, and the video was featured on local community access television through Dakota Media Access (Ogden 2015).

\section{The Life and Times of Reverend Case}

Missionaries have been both positive and negative figures in Indian history and in the history of the MHA Nation in particular. As a missionary, Rev. Case was part of a larger movement to bring a "civilizing" influence to Native Americans that was an additional way to break up Indian communities alongside federal government policies of termination at the time. There are some ways, however, in which Case did not fit in that mold-such as taking an active stance on behalf of the community for political causes, being inspired by the work of action anthropologist Sol Tax, and encouraging people to be proud of their heritage. ${ }^{14}$ While they began with a mission to prepare people living on the reservation to "live in the white world," Rev. Case and his wife Eva later interpreted Native experience to outsiders and advocated on their behalf (Maxfield 1986). Eva is quoted in a 1965 article in the Bismarck Tribune, "We learned more from the Indian people than they did from us" (Case and Case 1977, 546). Rev. Case both defended missions and noted how rapid change and efforts to disrupt traditional ways in the community were a cause for concern, setting up his efforts in opposition to the US government-an antagonism that would grow as planning 


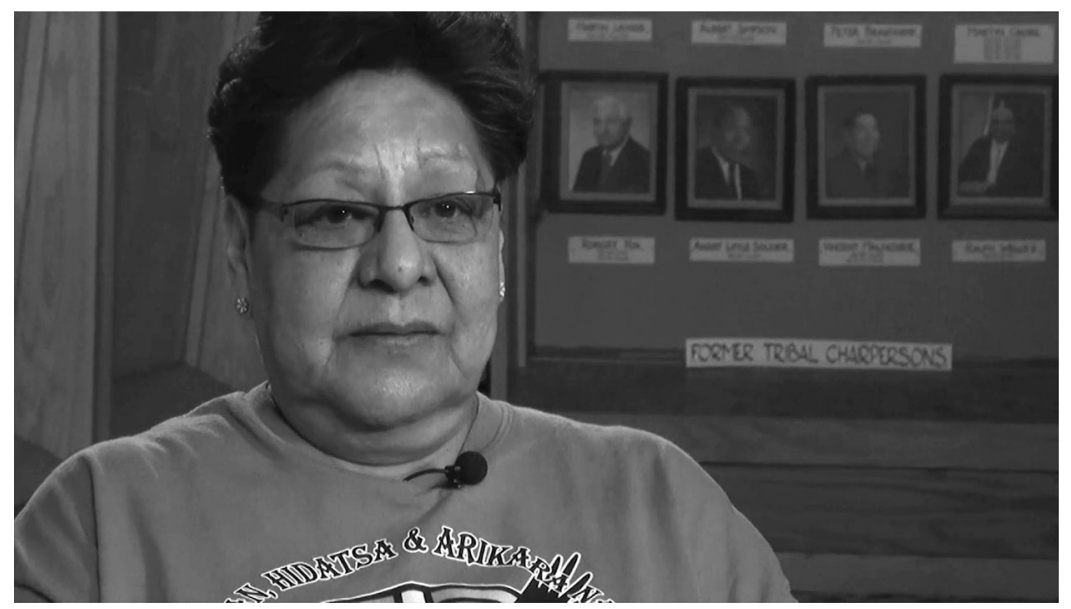

Fig. 3. Bobbi Larson, video still.

for the Garrison Dam got underway. He conducted a letter-writing campaign against the Garrison Dam and created a video, Grandmother River, which he brought to the US Congress to try to dissuade them from approving the dam.

Bobbi Larson, an MHA community member, high school teacher, and complexity that we were challenged with capturing in our representations of this figure in her community (figure 3): "I guess you could say that I'm a missionary, coming home. And hopefully I can make an impact like Reverend Case did. You know, even though we're two different colors, I think we can still blend. And from my studies about missionaries, I just honestly cannot say good things about them in the past. But today, 28 Reverend Case, I guess, when he's brought to mind, reminds me of what 29 one missionary can do." ${ }^{15}$ She sees the general figure of the missionary 30 as negative but this specific man as someone who cared for her family.

Marilyn Hudson pointed to this complexity while also explaining the 32 importance of oral history as a method. She introduced the documentary 33 by saying,

Not only has the role of the missionary, the role of the church, as well 35 as many other things has changed in the last generation ... the leadership has changed, Indian people have changed, the world has changed. 
So, when we entered the era of what they call political correctness, and a lot during the 6os, the revolution of a lot of political thought, religious thought and so forth-the role of the missionaries on Indian reservations also came under a certain amount of scrutinization.

She explained the value of her point of view as someone who lived through these times: "My own feeling is that you cannot analyze something unless you participated in it . . unless you were actually, say, a member of that congregation, a student at that school, a resident at that boarding school, and so forth-I don't really think you can speak with firsthand knowledge. So," she concluded, "I think over the years a lot of our missionaries and churches have gotten, like, a bad rap from people who weren't there, to explain. My own opinion is that our churches and our missions did a good job in ... attending to the sick, helping people in need-which they still do today"16

These opening comments to My Cry Gets Up to My Throat point to important messages that our partners wanted to share with their audiences, whether they are MHA Nation members or the broader public. They explain how and why the missionary is a complex figure in Native communities and highlight the importance of Native accounts of Native experiences. Or, as Juanita Helphrey put it at the video's conclusion, "We have stacks of books ... pages after pages of stories told from the Native American and years ago it wasn't like that at all.... And it's gratifying to know that. So, the truth will be told, a perspective will be realized, I think, from our point of view—that's the best part." As Juanita suggests, telling MHA history from an MHA perspective is empowering and future-oriented.

Similarly, as Julie Cruikshank's (2002) and Keith Basso's (1996) scholarship eloquently demonstrates, stories and narratives are not just about the past; they are vehicles for communicating something, often moral lessons, about the present to a specific listener. Oral history is a way of historicizing the present, it provides an understanding of the present by situating it with respect to experiences of the past. This became clear as elders recalled Rev. Case and their associated memories of living through the damming of the Missouri River and the inundation of their homelands in the 1950s, and then without prompting turned their narrative to the oil boom in North Dakota, and on their reservation, today. 


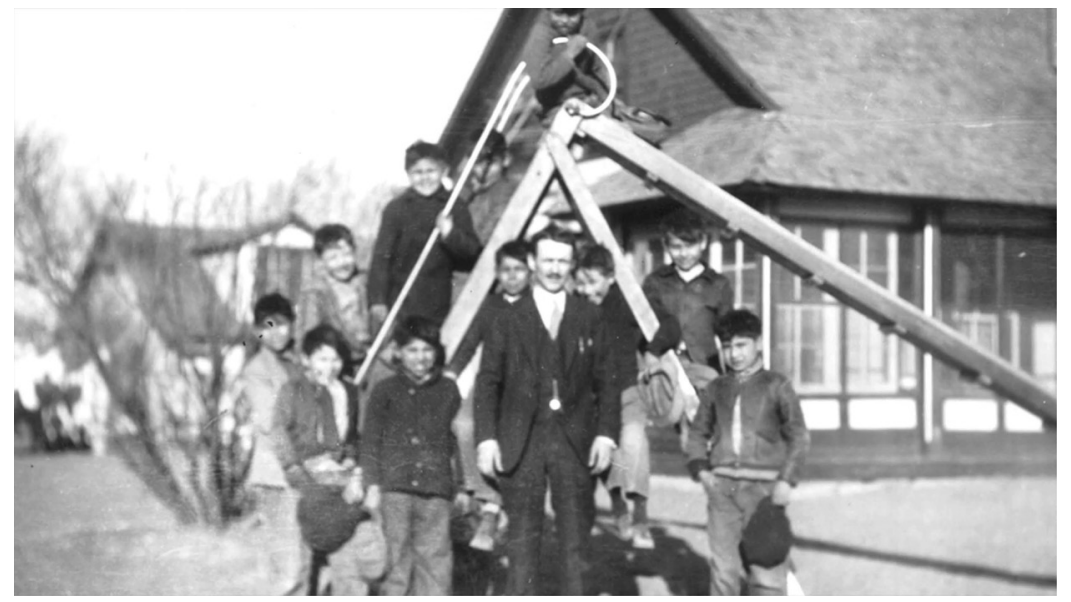

Fig. 4. Reverend Case with children near the school in Elbowoods, which was later flooded by the Garrison Dam, video still.

In My Cry Gets Up to My Throat, community members describe Rev. Case as a busy man, who always wore a suit, knew everyone's name, and warmly greeted everyone he encountered. What has emerged from various oral history accounts is not so much Rev. Case's role as a ministerthough there is talk about that, and about his voice as he sang in church. But more so, there is an appreciation for the kind of man he was, from a child's perspective (figure 4 ). These elders were small children at the time, so it is no wonder their personal recollections mainly focused on such views.

Community members also explain how the dam, and missionization,

Getting back to Elbowoods, I sure wish we had that community, because then we were whole. Now we're spread all over. . . . I believe that once they split the communities up-and see that's always been the government's way of killing us off. Just put it bluntly: exterminating us . . what better way than to turn people against each other. ${ }^{17}$ 
They describe what it felt like to see their homes go underwater, getting relocated to unfamiliar places with unfamiliar people, feeling powerless to stop the government's actions, and how Rev. Case was involved throughout.

Not included in the video, but along similar lines, Eva Case explains from her own perspective in 1969, "Garrison Dam. That story has been told so many times, I wonder if I need to repeat!” She goes on to explain:

The people were unaware of this until about 1947 when stakes began to appear marked U.S.B.M. Inquiry proved that what was happeningone Indian interpreted them as "You Scalawags Better Move." Move they finally did, but not without a fight in which Harold was deeply involved. He helped them form the Indian Defense Association-of which he was elected secretary. This involved much letter writing, hundreds of meetings, trips to Washington, D.C., and even then the fight to save their beautiful valley and "Grandmother River," was lost. But the price paid for the land for the lake was raised from $\$ 2$ million to $\$ 12$ million. (Case and Case 1977, 321)

She concludes noting that while they could not stop the dam, through their lobbying they at least were able to increase the compensation received by the tribe.

\section{Historicizing the Present and the Dysplacement of the MHA Nation}

What we learned from the process of conducting oral history about Rev. Case and the times in which he lived was that elders had a unique standpoint in understanding the oil boom in their community today. Their perspective, which could only be gained from their lived experience being at Fort Berthold in the 1950s, illustrates how their tribal community has been doubly displaced: through relocation in 1952 away from their homelands on the Missouri River bottom, and then today as they remain in place in their new home but are "dysplaced" (Jackson 2011), whereby their home no longer looks, smells, or feels familiar due to the oil boom. In Bernadine Young Bird's words, the oil boom made her feel that it is "not our land anymore," that we are "alienated" and that you "feel like a stranger in your own home" where we are "trying to get back in again." ${ }^{18}$ The oil boom is "seen as a kind of an attack on us. 
In our own land. We're not being displaced like the Garrison Dam, but we're having to stay here and still live under those conditions." ${ }^{19}$

As Mr. Bear noted, there are many community members who do not know this history or understand how it shapes their lives today. Like many other interviewees, without solicitation, he moved from the past and the Garrison Dam to the oil boom today: "And to a lot of our leaders, to them, this lake's always been there. You know, to our young people, this lake's always been there. It's a place to swim, and you get the money and buy yourself a boat and enjoy that lake. But us older people know what's underneath that water. A lot of our cemeteries, our graves, our loved ones, our ancestors, are underneath that water." He continued, "We wish that it would just simply go and dry up, then we can move back home. It'd probably be a muddy place to be, but it would still be our home. But we don't own it anymore either, so. So that's another reality that we have to live with." He concluded:

I think the oil boom in itself is another story that needs to be told. I think a lot of people got affected by it, you know, in more ways than one. Some people don't even have land, some people are not even benefiting off of it. But their grandparents probably had land underneath the river. So I think all the enrolled members should benefit from it because of our ancestry. You know, we own all this land, and when you hear the news, they're always talking about the Bakken. And nobody ever talks about the Indians owning all this. ${ }^{20}$

Ms. Larson conjured the most vivid image of how these two periods in

It's happening all over again. . . The oil boom. It is destroying us. . . When they were going to flood Elbowoods, they didn't tell them. . . . They went sneakily all over the place, put their little yellow flags up, and ended up, one day, saying, "Sign this paper." And that's why you see George Gillette crying as he signs that paper [releasing tribal lands for the Garrison Dam]: because he was choiceless. And you ... [can] see it today, where [it's] Marathon Oil: "Sign this paper."

Gerry Nagel explains how oil companies came to community mem- 


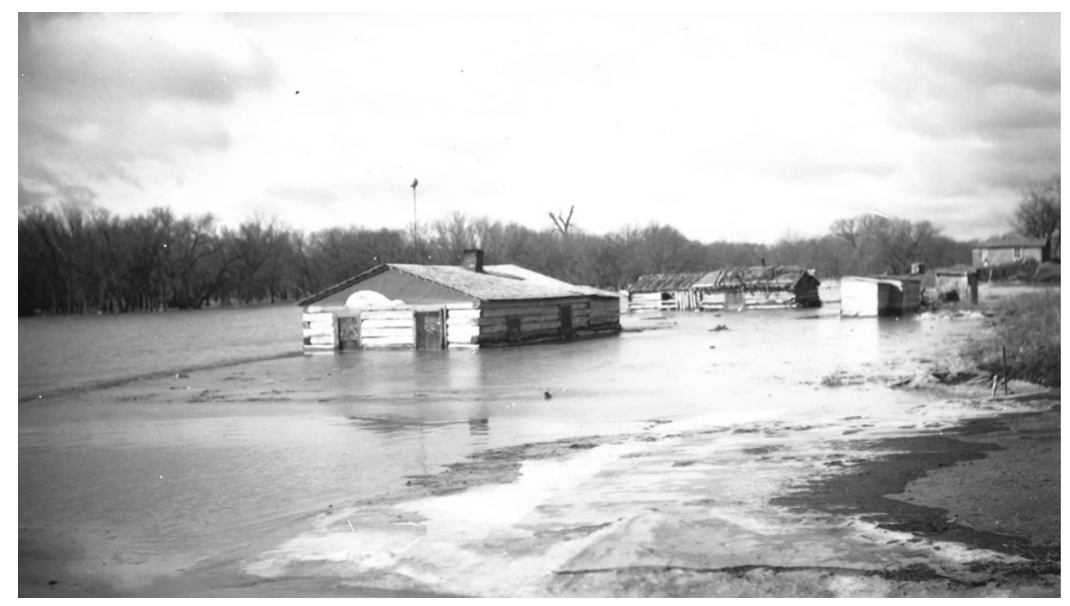

Fig. 5. Home being inundated by rising waters from the Garrison Dam at Fort Berthold Reservation, 1952, video still.

crop in. And this guy drives up in a suit, he's got all these papers for you. There's no oil wells around, he's leasing that land for five bucks an acrewhat are you going to do? You're going to sign. And that's how it's done. But it's always way ahead of time. They [oil companies] have it all pretty well strategized where they're going to go, you know." ${ }^{22}$

Edwin Benson-often referred to as the "last Mandan speaker," and the person to whom many community members seemed to respond to particularly when viewing the video-during our interview and without prompting said, "Let me just mention something that run through my mind here about a year ago or less ..." He goes on in a way that, during the screening sessions, clearly gave people pause to think and sparked conversation. Mr. Benson says in the video that it gives him "the chills to see so many oil wells in North Dakota.... I guess it's all right to be rich.... For some people it would be nice, 'cause they had it tough ... and if they receive all this money to live nice, then that's good, there's nothing wrong with it. But it's the idea of thinking of tomorrow, or the next day, or the next year, year after that-what's going to happen. We don't know that. See, nobody knows that." ${ }^{23}$ 


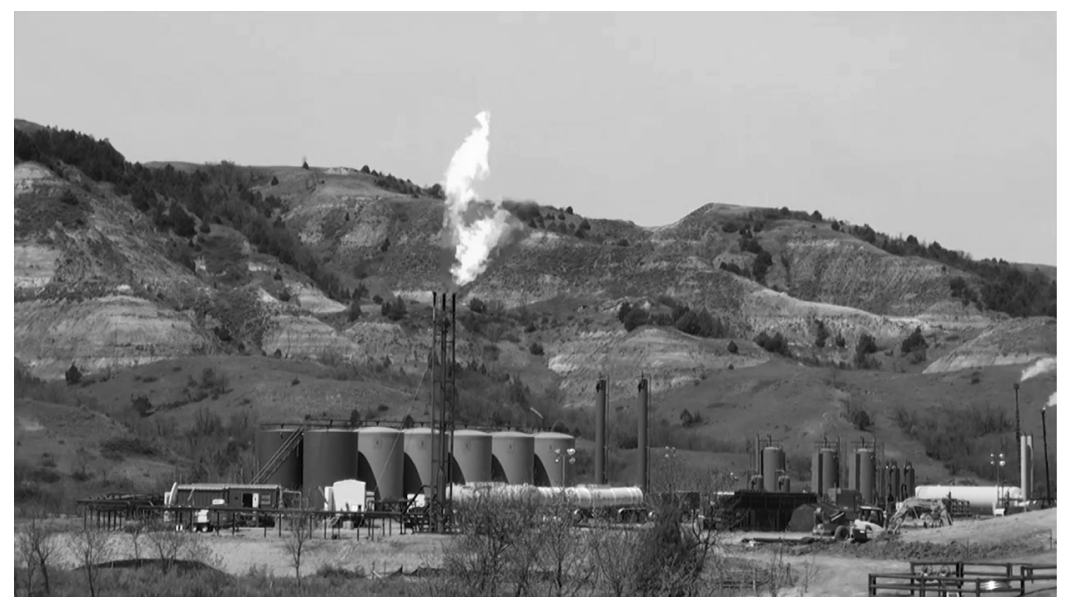

Fig. 6. Gas flare and tanks at Fort Berthold Reservation, 2014, video still.

\section{Community Screenings, Community Conversations}

The documentary included a number of themes, such as the complex figure of the missionary, the tension between forced assimilation and tion as feeling similar to the oil boom today for those who experienced both in their lifetime. Because elders have living memory of both the dam (figure 5) and the oil boom today (figure 6), they have a different perspective than younger generations about what is happening in their community. People responded to this in small group discussions after screenings. We conducted five draft video screenings in May 2014, and three final cut screenings in November 2014 (which, based on feedback, led to minor changes before distribution). About thirty-five people par28 ticipated in May and around twenty in November.

The draft screenings were held in May 2014. At the United Church 30 of Christ film screening, an MHA woman rose after the end of the film and asked, "What is your goal with the film? What are you going to do 32 with it?" I replied that it is up to the community, "It's yours to use as you 33 see fit." Juanita Helphrey suggested breaking it into chapters and adding reflection questions for use in schools. Group discussion followed that 


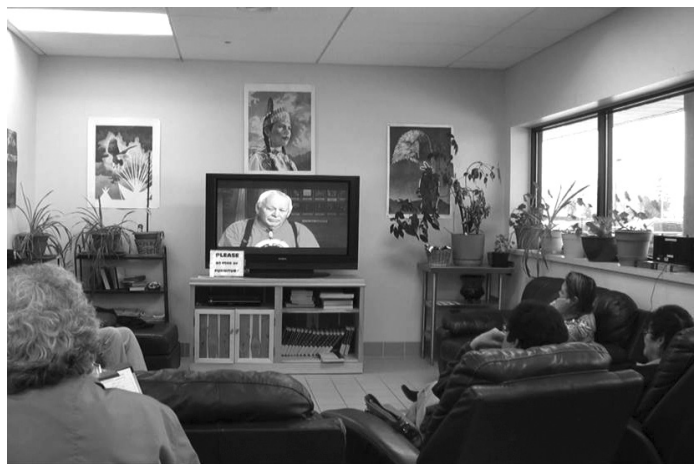

Fig. 7. Draft film screening at North Lights Community Center. Photo by author.

spanned a number of diverse topics from the care of cemetery grounds to oil and land rights. After the movie we had lunch in small groups around several tables. Those at my table suggested we continue the research and document the oil boom today. Another person mentioned that there are 14,000 enrolled members in the tribe now, including six millionaires; but the money is not reaching everyone. We talked for quite some time about land issues-how the entire reservation was allotted, and there was never tribally controlled land, or a council, until after the Indian Reorganization Act of 1934. Many people had sold their allotted land to the tribe because in the past it was their only source of wealth. Today, older people get most of the oil money, one person explained, because they still own the land. Community members also talked about how young people do not go to school and there is a lot of absenteeism throughout all the grades. Kids now do not think education is necessary because they will be rich and will not have to work when they grow up.

At an elders lunch at the Northern Lights Community Center (figure 7), Marilyn Hudson mentioned that the last time they were really selfsufficient with no public assistance was before the dam. After the dam, they moved to non-Native places like Parshall with no jobs. Today, there are more Indians than white people living there, she added. At a senior lunch hosted at the Arikara Cultural Center, a woman explained how Rev. Case had told her brother to get an education and leave the reservation because Indian life was no longer; today her brother regrets taking that advice. She was told that Rev. Case later apologized for 
saying he should leave. The Nueta Hidatsa Sahnish College president, Twyla Baker-Demaray, commented after the screening at the college, "This [documentary] would be a great advocacy or education tool for whoever is in our state legislature, congressional representatives, the state as a whole." And at the conclusion of the screening at the Three Tribes Museum, with tears in his eyes, Mr. Mandan said that the film had "brought up a lot of old wounds." In response, I asked the group whether this was a story they were comfortable with, whether we should show it more publicly. Barbara Bear, widow of James Bear who had passed away since our interview for the documentary, said yes, definitely. Mr. Mandan added that it opened old wounds, but it is good to see and important. It needs to be remembered.

Final screenings were hosted in November 2014. Ideas and concerns about home and questions about the oil boom came from elders and young people in the final screenings. At the Congregational Church in Parshall, Pastor Levine, who is non-Native and whose congregation is mainly MHA elders, commented that what home means is "something different for Native people." People do return, she added, they came back after relocation, but "it's hard to reestablish home. It's still not here, it's under the water," she said, echoing Mr. Bear's comments in the video. At the Nueta Hidatsa Sahnish College, several kids between the ages of eleven and thirteen were present. The screening became an opportunity for a mother to discuss this difficult time with her kids. Her eleven-year-old daughter asked after the screening, "What is fracking?" "Were the tribes consulted before the Bakken?" "Why do people suck?" Her mother and I jointly answered all her questions, with her mother explaining everything from what she had learned from her family about Garrison Dam to what the Keystone Pipeline is. Again, at this screening, it was agreed that a sequel about contemporary life should be produced, and the president of the Nueta Hidatsa Sahnish College agreed that the tribal college would be our main partner in the next film project. ${ }^{24}$

1 2 3 4 5 6 7 8 9

\section{Conclusion}

The relationships and materials that are being developed through digital 35

heritage projects and collaborative museum anthropology are utilizing 36 new media, producing new opportunities for historicizing the present,

(1)

일

(1)


and developing new collections for museums and tribal communities alike. Given the troubled history and relations among US tribes, anthropologists and collectors, and museums (Ames 1992; Clifford 1997, 188219; Erikson et al. 2002; Jacknis 2002, 19-72; Stocking 1985), this video project, which included MHA tribal members and descendants of the MHA collection donor, arose from a unique partnership in museum and anthropological practice in which collaboration is usually considered only between the museum and the tribe being represented. Rather than only assembling individual oral history interviews as an archive for the university and tribal museums, community members requested that we produce an edited documentary from these interviews-which, in turn, created a need for a coherent narrative to emerge from our work. This narrative was achieved through an iterative review process with MHA community members.

I have worked on other kinds of collaborative projects with Indigenous peoples that produced such visual media as interactive websites (Shannon 2014c, 2012) and museum exhibits (Shannon 2014b), but this medium felt the most intimate and the most inviting to community editing, perhaps because this particular project was always intended primarily for internal community use, unlike the others. In any case, it became clear from the start and in the final screening that not only did the medium of video allow for increased access to research outcomes through online and DVD distribution, but it also increased the amount of feedback from and impact within the community. Unlike a scholarly article or book, or a website that requires internet connection, or an exhibit that is located away from home, video is something entirely approachable in its form and familiar in its use. A group can review it together, at a time and place convenient to them, whether by DVD or online as streaming video. It is something they can pass out to others and pass on to later generations. It is commonly found both in a museum archive and on a living room shelf. And, as was evident in responses to the documentary we created, beyond the messages that were being communicated about the past and today, the sensory experience of seeing elders and hearing their voices was powerful and moving for MHA community members. Seeing who was speaking mattered.

Through the oral history project and video production process, from the perspectives of tribal members and the collection donor family who 
are both represented in the video, there are major themes that emerged from our work together, highlighting the "hard truths of colonialism" and establishing visual sovereignty: the missionary and his role as a man, an 2 activist, a representative of the church; US policy as a constantly shifting context over time that ruptured families, land base, processes of knowledge transmission, and spiritual practices; the Garrison Dam as the inundation of homeland and relocation of MHA villages and an insidious imposition of assimilation policy; oil as a second coming of outsiders to the community taking advantage of land resources; and the importance of Native peoples telling their own histories for their own communities.

As our conversations continued in the MHA Nation over the following years with the start of the sequel documentary, we learned that the oil boom was consistently referred to at the biggest historical scale of major traumatic events in MHA history. When talking about the oil boom's effects many people began their explanation with smallpox and the Garrison Dam. This suggests important ways in which community members were historicizing the oil boom: first, that the "fracking boom" was considered to be one in a list of major traumatic disruptions and displacements in their history; second, that it is considered at a scale that the 1950 s and 1980 s oil booms are not; and third, they explained that they have been through worse before and are here to tell the story.

I came to see collaborative filmmaking as an important kind of decolonizing methodology. It was powerful to see how first perspective narratives, ethnographic methods, and the visual- portable, sharablemedium of video can produce intergenerational capacity for action (cf. Turner 1991, 304), instigating community dialogue and requests for teaching materials for young people in schools. Visual media provide a wonderful tool for telling stories from first person perspective, and creating meaningful sources of knowledge for Indigenous communities, and can be important for reflecting on and telling outsiders about their experiences. Through this process of slow museology that led to collaborative filmmaking, community members seized the opportunity to reflect on the present in light of the past, and, in turn through individual contribution and group discussion, to create a greater capacity for action to determine their future during another major transition period in their community's history.

3 4 5 6 7 8 9 10 


\section{Epilogue}

After the conclusion of the process of making and distributing $M y$ Cry Gets Up to My Throat and following suggestions from community members, I submitted and received a grant to work with community members on a sequel documentary about contemporary life in the oil boom. I even had funding to include a professional filmmaker this time. By the time we returned to begin work on the new documentary in 2016, the reservation had been overwhelmed with documentarians and news organizations coming in, shooting video, and telling their story. And as we learned in another project we developed with the tribal college (Burnaugh 2015; Wirfs-Brock 2015), teachers and community members had identified media as one of the negative impacts of the oil boom. As we continued to feel out community interest in a second documentary, we felt it lacking despite our invitations via radio and tribal newspaper (Phleger 2015). We listened to community concerns and shifted our work, and the awarded funds, to conducting community-based video workshops through something we called the MHA Collaborative Film Project. The workshops were coordinated with local co-facilitators from the community to teach people to shoot, edit, and share their own films (Shannon 2017). ${ }^{25}$

I was sitting at my desk in Colorado on a Tuesday afternoon in September 2017 when my phone dinged with an incoming text message from one of the MHA Collaborative Film Project's co-facilitators, Elijah Benson. He wrote, "Watching a cry gets up to my throat for my NAS [Native American Studies] class this evening. Hope u doing well!" The text was accompanied by a photo of the tribal college's Twin Buttes extension classroom. At the front of the room was a large, shared video screen with a classroom at the reservation's main campus in New Town, where they were projecting the film on a white board. Juanita Helphrey's insistence that the film be used for educational purposes was being realized, and this young man was kind enough to share the news with me as it was happening.

Dr. JENNIFER SHANNON is a museum curator and an associate professor of cultural anthropology at the University of Colorado, Boulder, and author of Our Lives: Collaboration, Native Voice, and the Making of the National Museum of the American Indian (https://sarweb.org/our-lives/). She is co-producer of NAGPRA Comics and co-host of SAPIENS: A podcast for everything human. 
1. State Historical Society of North Dakota, Video archives, Garrison Dam \& Reservoir Project.

2. For more on decolonizing museums, see, for example, Lonetree 2012 and C. Smith 2005. For decolonizing methods more generally, see L. Smith 1999. The effort to "decolonize the museum" is an important framework for guiding institutional practice and striving toward restorative justice; it is a process, not an achievement (or at most ever a partial one).

3. Originating community refers to the people from whom the items in a museum originate or the makers of the items. For example, the Mandan Hidatsa Arikara Nation is the originating community for Reverend Case's collection of items from their reservation. Decolonizing the museum also includes repatriation, discussed later.

4. As of August 12, 2015, the MHA Nation listed the total number of enrolled members as 14,663 (see census at http://www.mhanation.com/main2/departments/tribal _enrollment/TAT\%20Census\%20as\%20of\%208-12-2015.pdf, accessed 9/22/2015). In 2010, according to the North Dakota Indian Affairs Commission, the total population on the reservation was 5,915 (it is not indicated whether this includes non-Native or nonenrolled individuals), and the total number of enrolled members at that time was 10,400 (http://www.nd.gov/indianaffairs/?id=74, accessed 9/22/2015).

5. Personal communication, October 5, 2015.

6. Tribal historic preservation officers are officials of a federally recognized tribe in the US who serve the same function as state historic preservation officers but with respect to tribal lands. Their responsibilities include protecting and identifying historic places according to tribal values and protocols.

7. All involved would agree that those who were asked by our advisory group to participate in the oral history project were people who had known and appreciated the Rev. Case and his efforts in the community; most were Congregationalists or Christians (this does not exclude them from engaging in other forms of spiritual or religious practice). No doubt a different narrative might have emerged had different people been selected by our research partners.

8. Letter of support written by Calvin Grinnell for a grant application to support this research.

9. Although I had no training in video and film production, I took a week-long production class at Boulder Digital Arts to be better prepared for our next trip, when the video work would begin.

10. Rev. Case's children donated his collection of Mandan, Arikara, and Hidatsa items to the UCMNH after he had loaned it several times for exhibitions and for safekeeping. Rev. Case presided over many weddings, births, and funerals. In interviews MHA community members explained that many of the collection items were likely gifts for performing these duties: "The missionary could be counted on to extend financial help in all kinds of emergencies. Case kept records of loans and sometimes accepted artifacts as security; at other times he bought rare items outright" (Maxfield 1986, 18).

11. When staff at the State Historical Society of North Dakota viewed the MHA website, they offered to provide more than two thousand scanned photos from their Case Collection archive that were not available online and had no associated information. The 
13. All three of these individuals can be considered professionals in the representation of their communities to outsiders (Shannon 2015) and are often those who are quoted in newspaper articles, anthropological essays (see Murray et al. 2011), and historical accounts. They are supportive of and facilitate research and researchers who are interested in working with the MHA Nation.

14. Letter from Rev. Case to Joe Ben Wheat (UCMNH donor files), November 12, 1957: "One of these days perhaps we will have a more realistic handling of Indian Affairs. Just came back from the National Congress of the American Indians in Claremore Oklahoma. While there I heard Dr. Sol Tax give a most excellent address urging the powers that be to treat the Indian as a person, etc." Sol Tax directed an "action anthropology" project at Fort Berthold in 1950-53 to help aid the community in the inevitable relocation. Graduate students from the University of Chicago carried out the research.

15. Transcript of video interview with Ruperta (Bobbi) Larson, May 21, 2012. Emphasis added.

16. Transcript of video interview with Marilyn Hudson, May 21, 2012. Emphasis added.

17. Transcript of video interview with Ruperta (Bobbi) Larson, May 21, 2012.

18. Handwritten notes from interview, August 18, 2015. I asked her about the idea of "dysplacement" and she agreed that was an appropriate way to describe how she felt.

19. Transcript of video interview with Bernadine Young Bird, August 21, 2015.

20. Transcript from video interview with James Bear, May 21, 2012.

21. Transcript of video interview with Ruperta (Bobbi) Larson, May 21, 2012.

22. Transcript from video interview with Gerald Nagel, May 22, 2012.

23. Transcript of video interview with Edwin Benson, May 15, 2013.

24. The tribal college did maintain their partnership with us in what came next-by giving academic credits to those who attended our filmmaking workshops in the summer of 2016. The project radically changed from a documentary to community-created short films (Shannon 2017).

25. For more information, see the MHA Collaborative Film Project website at http:// mhacollaborativefilm.weebly.com/.

\section{Works Cited}

Ames, Michael M. 1992. Cannibal Tours and Glass Boxes: The Anthropology of Museums. 2nd rev. ed. Vancouver: UBC Press.

Archibald, Jo-Ann. 2008. Indigenous Storywork-Educating the Heart, Mind, Body, and Spirit. Toronto: UBC Press. https://www.ubcpress.ca/indigenous-storywork.

Basso, Keith. 1996. Wisdom Sits in Places: Landscape and Language Among the Western Apache. Albuquerque: University of New Mexico Press. https://www.amazon.com /Wisdom-Sits-Places-Landscape-Language/dp/0826317243.

Berman, Terri. 1988. "For the Taking: The Garrison Dam and the Tribal Taking Area." Cultural Survival, 1988. https://www.culturalsurvival.org/publications/cultural -survival-quarterly/taking-garrison-dam-and-tribal-taking-area.

Boast, Robin. 2011. "Neocolonial Collaboration: Museum as Contact Zone Revisited." Museum Anthropology 34 (1): 56-7o. https://doi.org/10.1111/j.1548-1379.2010.01107.x. Burnaugh, Nick. 2015. "Citizen Science Project in Early Stage." MHA Times, January 6. 
Butler, Udi Mandel, Laura Peers, Cara Krmpotich, and Pitt Rivers Museum. 2011. Everything Was Carved. Pitt Rivers Museum. https://vimeo.com/26104413.

Case, Harold, and Eva Case. 1977. 100 Years at Ft. Berthold: The History of Fort Berthold Indian Mission, 1876-1976. Bismarck: Author published.

Clifford, James. 1997. Routes: Travel and Translation in the Late Twentieth Century. Cambridge, MA: Harvard University Press.

Colwell, Chip. 2019. "Can Repatriation Heal the Wounds of History?" Public Historian (University of California Press) 41 (1): 90-110. https://doi.org/10.1525/tph.2019.41.1 .90 .

Cruikshank, Julie. 2002. "Oral History, Narrative Strategies, and Native American Historiography: Perspectives from the Yukon Territory, Canada." In Clearing a Path: Theorizing the Past in Native American Studies, edited by Nancy Shoemaker, 3-27. New York: Routledge.

Elder, Sarah. 1995. "Collaborative Filmmaking: An Open Space for Making Meaning, A Moral Ground for Ethnographic Film.” Visual Anthropology Review 11 (2): 94-101. https://doi.org/10.1525/var.1995.11.2.94.

Erikson, Patricia Pierce, Kirk Wachendorf, and Helma Ward. 2002. Voices of a Thousand People: The Makah Cultural and Research Center. Lincoln: University of Nebraska Press.

Fienup-Riordan, Ann. 1999. "Collaboration on Display: A Yup'ik Eskimo Exhibit at Three National Museums." American Anthropologist 101 (2): 339-58. https://doi.org/10 .1525/aa.1999.101.2.339.

Fixico, Donald. 2000. The Urban Indian Experience in America. Albuquerque: University of New Mexico Press. https://unmpress.com/books/urban-indian-experience -america/9780826322166.

Glass, Aaron. 2004. In Search of the Hamat'sa: A Tale of Headhunting (film). Watertown, MA: Documentary Educational Resources. https://store.der.org/in-search-of-the -hamatsa-p743.aspx.

Hennessy, Kate, Natasha Lyons, Stephen Loring, Charles Arnold, and Mervin Joe. 2013. "The Inuvialuit Living History Project: Digital Return as the Forging of Relationships Between Institutions, People, and Data." Museum Anthropology Review 7 (1-2): 44-73.

Herle, Anita. 1990. "Medium and Message in an Anthropological Exhibit: Curating 'The Nagas.” SVA Review 6 (2): 55-61. https://doi.org/10.1525/var.1990.6.2.55.

Jacknis, Ira. 2002. The Storage Box of Tradition: Kwakiutl Art, Anthropologists, and Museums, 1881-1981. Smithsonian Series in Ethnographic Inquiry. Washington, DC: Smithsonian Institution Press.

Jackson, Deborah Davis. 2011. "Scents of Place: The Dysplacement of a First Nations Community in Canada." American Anthropologist 113 (4): 606-18. https://doi.org/10 .1111/j.1548-1433.2011.01373.x.

Jones, Alison, and Kuni Jenkins. 2008. "Rethinking Collaboration: Working the Indigene-Colonizer Hyphen." In Handbook of Critical and Indigenous Methodologies, edited by Norman Denzin, Yvonna Lincoln, and Linda Smith, 471-86. Thousand Oaks, CA: Sage. https://doi.org/10.4135/9781483385686.n23.

Lawson, Michael. 2009. Dammed Indians Revisited: The Continuing History of the PickSloan Plan and the Missouri River Sioux, 1944-1980. Pierre: South Dakota Historical Society Press. https://www.sdhspress.com/books/dammed-indians-revisited-the -continuing-history-of-the-pick-sloan-plan-and-the-missouri-river-sioux.

2

3

4

5

6

7

8

9

10

11

12

13

14

15

16

17

18

19

20

21

22

23

24

25

26

27

28

29

30

31

32

33

34

35

36

37

38 
Lonetree, Amy. 2012. Decolonizing Museums. Chapel Hill: University of North Carolina Press. https://uncpress.org/book/9780807837153/decolonizing-museums/.

Maxfield, Christyann Ranck. 1986. Goodbye to Elbowoods: The Story of Harold and Eva Case. Bismarck: North Dakota Heritage Center, State Historical Society of North Dakota.

Menzies, Charles. 2015. "In Our Grandmothers' Garden: An Indigenous Approach to Collaborative Film." In Participatory Visual and Digital Research in Action, edited by Aline Gubrium, Krista Harper, and Marty Otañez, 103-14. New York: Routledge.

Mithlo, Nancy Marie. 2004. "Red Man's Burden': The Politics of Inclusion in Museum Settings." American Indian Quarterly 28 (3-4): 743-63.

Murray, Wendi Field, María Nieves Zedeño, Kacy L. Hollenback, Calvin Grinnell, and Elgin Crows Breast. 2011. "The Remaking of Lake Sakakawea: Locating Cultural Viability in Negative Heritage on the Missouri River." American Ethnologist 38 (3): 468-83. https://doi.org/10.1111/j.1548-1425.2011.01317.x.

Ogden, Eloise. 2015. "My Cry Gets Up to My Throat': Documentary Reflects on Fort Berthold Missionaries, Garrison Dam \& Oi Boom." Minot Daily News, February 13.

Olin, Chuck. 1983. Box of Treasures (film). Watertown, MA: Documentary Educational Resources. https://store.der.org/mobile/box-of-treasures-p209.aspx.

Phleger, Atty. 2015. "Open Invitation to Participate in Documentary Film." MHA Times, August 26.

Raheja, Michelle. 2007. “Reading Nanook's Smile: Visual Sovereignty, Indigenous Revisions of Ethnography, and Atanarjuat (The Fast Runner)." American Quarterly 59 (4): 1159-85. https://doi.org/10.1353/aq.2007.0083.

Shannon, Jennifer. 2012. "IShare Experience: On Working with the National Taiwan Museum." Taiwan Natural Science 31 (3): 10-17.

_ . 2014a. My Cry Gets Up to My Throat-Public Version. https://vimeo.com /118650096/.

- 2014b. Our Lives: Collaboration, Native Voice, and the Making of the National Museum of the American Indian. Santa Fe: SAR Press.

_ 2014c. "Project iShare: Sharing Our Past, Collecting for the Future." In Museum as Process: Translating Local and Global Knowledges, edited by Raymond Silverman, 1st edition, 67-89. London: Routledge.

- 2015. "Artifacts of Collaboration at the National Museum of the American Indian." New Proposals: Journal of Marxism and Interdisciplinary Inquiry 7 (2): 37-55.

_ 2017. "On Being a Tentative Anthropologist: Collaborative Anthropological Research with Indigenous Peoples in North America." In Practicing Ethnography: A Student Guide to Method and Methodology, edited by Lynda Mannik and Karen McGarry, 58-65. Toronto: University of Toronto Press.

- 2018. "3 Tribes at the Heart of the Fracking Boom." Scientific American Blog Network. https://blogs.scientificamerican.com/voices/3-tribes-at-the-heart-of-the -fracking-boom/.

Silverman, Raymond, ed. 2014. Museum as Process: Translating Local and Global Knowledges. 1st edition. London: Routledge.

Simpson, Moira. 2009. "Museums and Restorative Justice: Heritage, Repatriation and Cultural Education." Museum International 61 (1-2): 121-29. https://doi.org/10.1111/j .1468-0033.2009.01669.x. 
Singer, Beverly. 2001. Wiping the War Paint off the Lens: Native American Film and Video. Minneapolis: University of Minnesota Press. https://www.upress.umn.edu/book -division/books/wiping-the-war-paint-off-the-lens.

Smith, Claire. 2005. "Decolonising the Museum: The National Museum of the American Indian in Washington, DC." Antiquity 79(304): 424-39. https://doi.org/10.1017 /S0003598X00114206.

Smith, Linda Tuhiwai. 1999. Decolonizing Methodologies: Research and Indigenous Peoples. New York: Zed Books.

Stocking, George W., ed. 1985. Objects and Others: Essays on Museums and Material Culture. History of Anthropology, vol. 3. Madison: University of Wisconsin Press.

Thomas, Nicholas. 2010. “The Museum as Method." Museum Anthropology 33 (1): 6-10. https://doi.org/10.1111/j.1548-1379.2010.01070.x.

Turner, Terence. 1991. "Representing, Resisting, Rethinking: Historical Transformations of Kayapo Culture and Anthropological Consciousness." In Colonial Situations: Essays on the Contextualization of Ethnographic Knowledge, edited by George Stocking Jr., 285-313. Madison: University of Wisconsin Press.

Wirfs-Brock, Jordan. 2015. "Citizen Science on the Rez-Kids, Science and North Dakota’s Oil Boom." Inside Energy. Prairie Public Radio. http://insideenergy.org/2015/11/23 /citizen-science-on-the-rez-kids-science-and-north-dakotas-oil-boom/. 


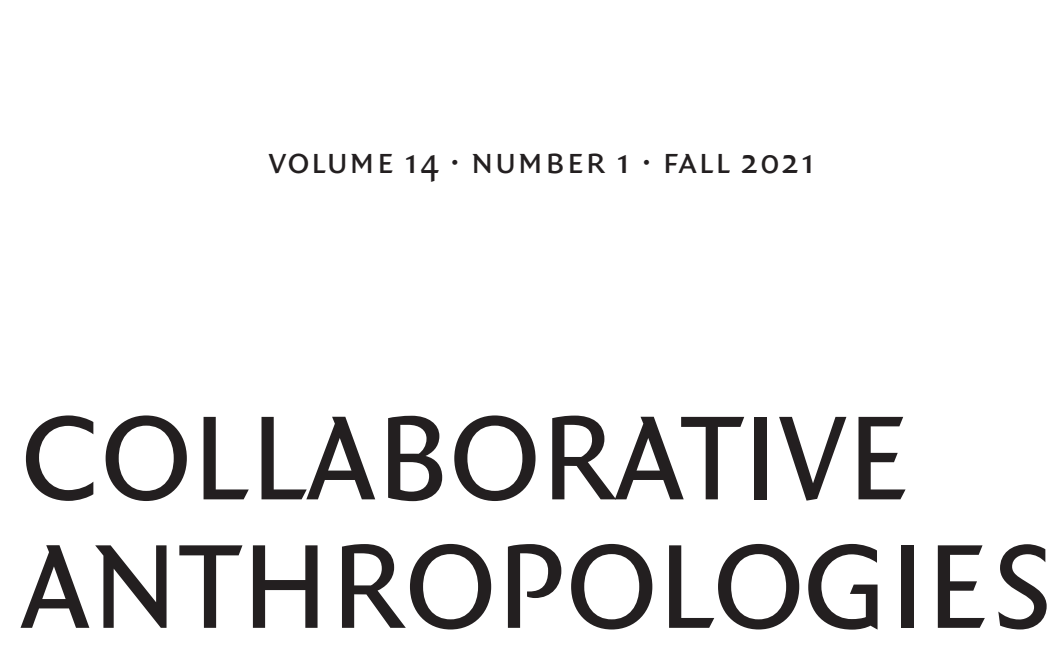

Edited by Charles R. Menzies

COLLABORATIVE 9

PUBLISHED BY THE UNIVERSITY OF NEBRASKA PRESS 